\title{
DIFFERENCES OF ANAEMIA STATUS, NUTRITIONAL STATUS AND NUTRITIONAL INTAKE ADOLESCENT GIRL IN URBAN AND RURAL AREAS
}

\author{
Miratul Haya, Elvi Destariyani \\ Politeknik Kesehatan Kementerian Kesehatan Bengkulu \\ Jl.Indra Giri No.3, Padang Harapan- Kota Bengkulu, Kode Pos 38225 \\ E-mail: miratulhaya@gmail.com
}

Submitted: $28^{\text {th }}$ February 2020; Accepted: $12^{\text {th }}$ June 2020

https://doi.org/10.36525/sanitas.2020.7

\begin{abstract}
Adolescence is a transition from childhood to adulthood which is marked by a number of biological, cognitive, and emotional changes. Adolescent nutritional status is very influential on brain growth needed for cognitive and intellectual processes. The emergence of adolescent nutrition problems is basically due to the wrong eating consumption behavior. A diet that is not balanced with the body's nutritional needs will cause the body to lack iron. Persistent iron deficiency in adolescent girls can cause hemoglobin $(\mathrm{Hb})$ levels in the blood to decrease and cause anemia. The objective was to analyze differences in anemia status, nutritional status and nutritional intake of adolescent girls in urban and rural areas. This type of research is cross sectional with research sites in SMAN 2 Bengkulu City and SMAN 4 Bengkulu Utara. The sample of the study was young women who met the inclusion and exclusion criteria of 130 people. Data collected was characteristic of sample data obtained through questionnaires, anemia status data obtained from $\mathrm{Hb}$ examination using a digital hemoglobinometer, nutritional status data obtained by anthropometric index IMT / U and nutritional intake data, data were collected using the SQ-FFQ method. Data analysis using Independent t-test if the data with normal distribution and Mann Whitney $U$ test for data with abnormal distribution. The result is, there was no difference between anemia status, nutritional status and intake of vitamin $C$ in young women in urban and rural areas. There is a difference between protein intake and iron adolescent girls in urban and rural areas.
\end{abstract}

Keywords: anemia, nutritional status, nutritional intake

This is an open access journal, and articles are distributed under the terms of the Creative Commons Attribution-Non Commercial-Share Alike 4.0 License, which allows others to remix, tweak, and build upon the work non-commercially, as long as appropriate credit is given and the new creations are licensed under the identical terms.

(C)2020 Sanitas 


\title{
PERBEDAAN STATUS ANEMIA, STATUS GIZI DAN ASUPAN GIZI REMAJA PUTRI DI WILAYAH PERKOTAAN DAN PEDESAAN
}

\begin{abstract}
ABSTRAK
Remaja merupakan masa transisi dari masa kanak-kanak ke masa dewasa yang ditandai sejumlah perubahan biologis, kognitif, dan emosional. Status gizi remaja sangat berpengaruh pada pertumbuhan otak yang diperlukan untuk proses kognitif dan intelektual. Timbulnya masalah gizi remaja pada dasarnya dikarenakan perilaku konsumsi makan yang salah. Diet yang tidak seimbang dengan kebutuhan zat gizi tubuh akan menyebabkan tubuh kekurangan zat besi. Kekurangan zat besi terusmenerus pada remaja putri dapat menyebabkan kadar hemoglobin $(\mathrm{Hb})$ dalam darah berkurang dan menimbulkan anemia. Tujuan penelitian ini adalah menganalisis perbedaan status anemia, status gizi dan asupan gizi remaja putri di wilayah perkotaan dan pedesaan. Metode penelitian yang digunakan adalah cross sectional dengan lokasi penelitian di SMAN 2 Kota Bengkulu dan SMAN 4 Bengkulu Utara. Sampel penelitian adalah remaja putri yang memenuhi kriteria inklusi dan eksklusi sebesar 130 orang. Data yang dikumpulkan adalah data karakteristik sampel yang didapat melalui kuesioner, data status anemia diperoleh dari pemeriksaan kadar $\mathrm{Hb}$ menggunakan hemoglobinometer digital, data status gizi diperoleh dengan indeks antropometri IMT/U dan data asupan gizi yang data dikumpulkan menggunakan metode $S Q-F F Q$. Analisis data menggunakan uji Independent t-test jika data dengan sebaran normal dan Mann Whitney $U$ test untuk data dengan sebaran tidak normal. Hasilnya, tidak ada perbedaan antara status anemia, status gizi dan asupan vitamin $\mathrm{C}$ remaja putri di wilayah perkotaan dan pedesaan. Ada perbedaan antara asupan protein dan zat besi remaja putri di wilayah perkotaan dan pedesaan.
\end{abstract}

Kata kunci : anemia, status gizi, asupan gizi

\section{PENDAHULUAN}

Pertumbuhan pada masa remaja terjadi sangat cepat (Adolescence Growth Spurt). Kecepatan pertumbuhan yang tinggi menyebabkan remaja membutuhkan makanan yang mengandung zat-zat gizi yang cukup besar (Soetjiningsih, 2010). Menurut Sediaoetama (2010) remaja merupakan salah satu kelompok rentan gizi. Oleh sebab itu, zat gizi yang dibutuhkan remaja harus terpenuhi baik dari segi kualitasnya maupun kuantitasnya. Ketidakseimbangan antara asupan dan kebutuhan atau kecukupan akan menimbulkan masalah gizi. Salah satu masalah gizi yang biasanya sering dialami pada masa remaja adalah anemia (WHO, 2008). Anemia merupakan suatu keadaan dimana jumlah hemoglobin $(\mathrm{Hb})$ dalam darah kurang dari kadar normal, yaitu $<12 \mathrm{~g} / \mathrm{dl}$ (Widyastuti dkk, 2010).

Prevalensi anemia di dunia diperkirakan 1,32 miliar jiwa atau sekitar 25\% dari populasi manusia di dunia, dimana angka tertinggi benua Afrika sebanyak 44,4\%, benua Asia sebanyak 25\%-33,0\% dan terendah di benua Amerika Utara sebanyak 7,6\% (WHO, 2015).

Berdasarkan data Riset Kesehatan Dasar (Riskesdas) 2013 secara nasional terdapat $22,7 \%$ perempuan tidak hamil usia $\geq 15$ tahun yang kadar hemoglobin kurang dari batas normal dengan proporsi $22,4 \%$ di perkotaan dan $23,0 \%$ di pedesaan. 
Demikian juga tantangan anemia pada ibu hamil dari 37,1\% pada Riskesdas 2013 yang justru mengalami peningkatan menjadi 48,9\% pada Riskesdas 2018 dengan proporsi anemia terbesar ada di kelompok umur 15-24 tahun (Balitbangkes, 2013, 2018).

Status gizi remaja sangat berpengaruh pada pertumbuhan otak yang diperlukan untuk proses kognitif dan intelektual. Remaja putri merupakan calon ibu di masa depan dan jika seorang ibu hamil dengan kondisi kurang energi kronis (KEK) akan membawa dampak bagi janin yang sedang dikandungnya (Teji et all, 2016). Berdasarkan hasil Riskesdas 2013 di Propinsi Bengkulu terdapat 5,8\% remaja kurus umur 16-18 tahun (Balitbangkes, 2013).

Diet yang tidak seimbang dengan kebutuhan zat gizi tubuh akan menyebabkan tubuh kekurangan zat besi. Kekurangan zat besi terus-menerus pada remaja putri dapat menyebabkan kadar hemoglobin $(\mathrm{Hb})$ dalam darah berkurang dan menimbulkan anemia (Arisman, 2010). Protein berperan penting dalam transportasi zat besi di dalam tubuh oleh karena itu, kurangnya asupan protein akan mengakibatkan transportasi zat besi terhambat sehingga akan terjadi defisiensi besi. Hasil survei diet total untuk rerata asupan protein remaja putri umur 2-8 tahun di wilayah pedesaan Bengkulu sebesar 46,7 gr sedangkan di wilayah perkotaan Bengkulu sebesar 69,6 gr (Balitbangkes, 2014).

Program penanggulangan anemia lebih terfokus pada ibu hamil padahal remaja putri adalah calon ibu yang harus sehat agar melahirkan bayi sehat, sehingga akan tumbuh dan berkembang menjadi sumber daya manusia yang berkualitas. Anemia dapat dicegah melalui cara sederhana yaitu dengan melakukan pola makan yang baik. Jenis bahan makanan yang seimbang apabila dikonsumsi setiap hari akan dapat memenuhi kebutuhan gizi tubuh remaja, sehingga kejadian defisiensi zat gizi berkurang (Brown et all, 2005).

Penelitian ini menganalisa mengenai perbedaan status anemia, status gizi dan asupan gizi pada remaja putri di Sekolah Menengah Atas Negeri (SMAN) 2 Kota Bengkulu dan SMAN 4 Bengkulu Utara. SMAN 2 Kota Bengkulu merupakan sekolah dengan kondisi daerah perkotaan dan terletak di pusat Kota Bengkulu. SMAN 4 Bengkulu Utara terletak di Kecamatan Kerkap Kabupaten Bengkulu Utara dengan kondisi geografis dataran berbukit-bukit dengan ketinggian 541 meter di atas permukaan laut. 


\section{METODE PENELITIAN}

Penelitian ini menggunakan pendekatan cross sectional dan lokasi penelitian di SMAN 2 Kota Bengkulu dan SMAN 4 Bengkulu Utara. Sampel adalah remaja putri yang berumur 16-18 tahun sejumlah 65 orang pada setiap kelompok sampel. Teknik pengambilan sampel menggunakan sistematik random sampling dan kriteria remaja putri yang menjadi sampel adalah tidak menderita penyakit kronis, tidak dalam kondisi menstruasi dan bersedia menjadi sampel penelitian dengan menandatangani formulir informed consent.

Pengumpulan data dilakukan dengan cara: 1) Data karakteristik responden diperoleh melalui wawancara dengan kuesioner terstruktur, 2) Data status anemia diperoleh dari pemeriksaan kadar hemoglobin $(\mathrm{Hb})$ menggunakan hemoglobinometer digital, 3) Data status gizi diperoleh dengan indeks antropometri IMT/U menggunakan nilai z-skor IMT, IMT dihitung sebagai berat badan dalam kilogram dibagi dengan kuadrat tinggi badan dalam meter $\left(\mathrm{kg} / \mathrm{m}^{2}\right)$, pengukuran berat badan dilakukan dengan menggunakan timbangan injak elektrik dan pengukuran tinggi badan menggunakan alat microtoise, 4) Data asupan gizi yang terdiri dari asupan protein, vitamin $\mathrm{C}$ dan zat besi dikumpulkan melalui pendekatan retrospektif SemiQuantitatif Food Frequency Questionnaire (SQ-FFQ) yang berisi jenis-jenis makanan yang biasa dikonsumsi responden, sebelum responden menjawab kuesioner ini, dijelaskan dahulu kepada responden untuk mengingat dan memperkirakan seberapa sering rata-rata mereka mengonsumsi bahan makanan tersebut dalam kurun waktu sebulan (per hari, per pekan dan sebulan terakhir atau tidak pernah dalam sebulan terakhir), total konsumsi jenis bahan makanan dalam satu hari dihitung untuk masing-masing zat gizi.

Analisa data untuk mengetahui perbedaan status anemia, status gizi dan asupan gizi pada remaja putri di perkotaan dan pedesaan dilakukan dengan Independent t-test jika data dengan sebaran normal dan Mann Whitney $U$ test untuk data dengan sebaran tidak normal.

\section{HASIL}

\section{Hasil}

Anemia merupakan suatu keadaan dimana kadar hemoglobin lebih rendah daripada nilai normal yang berbeda untuk setiap kelompok umur dan jenis kelamin. 
Kadar hemoglobin normal pada wanita umur $>15$ tahun adalah $\geq 12 \mathrm{~g} / \mathrm{dl}$ (WHO, 2015). Deskripsi status anemia remaja putri di wilayah perkotaan dan pedesaan dapat dilihat pada tabel 1 .

Tabel 1. Deskripsi Status Anemia Remaja Putri di Wilayah Perkotaan dan Pedesaan

\begin{tabular}{ccccc}
\hline \multirow{2}{*}{ Variabel } & \multicolumn{2}{c}{ Perkotaan } & \multicolumn{2}{c}{ Pedesaan } \\
\cline { 2 - 5 } & $\mathrm{n}$ & $\%$ & $\mathrm{n}$ & $\%$ \\
\hline Status Anemia & & & & \\
$-\quad$ Kadar Hb rendah $(<12,0 \mathrm{~g} / \mathrm{dl})$ & 17 & 26,2 & 21 & 32,3 \\
- Kadar Hb normal $(\geq 12,0 \mathrm{~g} / \mathrm{dl})$ & 48 & 73,8 & 44 & 67,7 \\
- & Rerata $\pm \mathrm{SD}$ & $12,87 \pm 1,78$ & \multicolumn{2}{c}{$12,43 \pm 2,06$} \\
\hline
\end{tabular}

Tabel 1 menunjukkan status anemia remaja putri yang dinilai berdasarkan kadar $\mathrm{Hb}$ adalah normal pada kedua kelompok remaja putri. Rerata nilai kadar $\mathrm{Hb}$ remaja putri di wilayah perkotaan sebesar $12,87 \mathrm{~g} / \mathrm{dl}$ dan $12,43 \mathrm{~g} / \mathrm{dl}$ pada remaja putri di wilayah pedesaan. Prevalensi status anemia berdasarkan kadar $\mathrm{Hb}$ rendah $(<12,0$ $\mathrm{g} / \mathrm{dl}$ ) pada remaja putri di wilayah perkotaan terdapat $26,2 \%$ yang lebih sedikit dibandingkan remaja putri di wilayah pedesaan $(32,3 \%)$.

Status gizi merupakan keadaan tubuh seseorang atau sekelompok orang yang diakibatkan oleh konsumsi, penyerapan dan penggunaan zat gizi makanan. Indikator yang digunakan untuk menentukan status gizi remaja putri secara antropometri adalah perhitungan Indeks Massa Tubuh menurut umur (IMT/U) dengan kategori menurut WHO 2005 (Kemenkes, 2011). Deskripsi status gizi remaja putri di wilayah perkotaan dan pedesaan dapat dilihat pada tabel 2.

Tabel 2. Deskripsi status gizi remaja putri di wilayah perkotaan dan pedesaan

\begin{tabular}{|c|c|c|c|c|c|}
\hline & \multirow{2}{*}{ Variabel } & \multicolumn{2}{|c|}{ Perkotaan } & \multicolumn{2}{|c|}{ Pedesaan } \\
\hline & & $\mathrm{n}$ & $\%$ & $\mathrm{n}$ & $\%$ \\
\hline \multicolumn{6}{|c|}{ Status Gizi } \\
\hline- & Kurus $(\geq-3,0 \mathrm{SD}-<-2 \mathrm{SD})$ & 1 & 1,5 & 2 & 3,1 \\
\hline- & Normal $(\geq-2,0$ SD $-\leq 1,0$ SD) & 49 & 75,4 & 57 & 87,7 \\
\hline- & Gemuk ( $>1,0 \mathrm{SD}-\leq 2,0 \mathrm{SD})$ & 7 & 10,8 & 2 & 3,1 \\
\hline- & Obesitas (>2,0 SD) & 8 & 12,3 & 4 & 6,2 \\
\hline- & Rerata $\pm \mathrm{SD}$ & \multicolumn{2}{|c|}{$0,38 \pm 1,18$} & \multicolumn{2}{|c|}{$0,01 \pm 1,12$} \\
\hline
\end{tabular}


Tabel 2 menunjukkan rerata nilai z-skor (IMT/U) remaja putri pada kedua kelompok adalah normal yaitu 0,38 SD pada remaja putri di wilayah perkotaan dan 0,01 SD pada remaja putri di wilayah pedesaan. Prevalensi remaja putri dengan status gizi kurus lebih banyak terdapat di wilayah pedesaan dibandingkan remaja putri di wilayah perkotaan.

Penilaian asupan gizi (protein, vitamin $\mathrm{C}$, dan zat besi) pada remaja putri yang menjadi subjek penelitian dilakukan menggunakan metode $S Q-F F Q$. Kecukupan gizi merupakan rata-rata zat gizi setiap hari bagi semua orang menurut golongan umur, jenis kelamin, ukuran tubuh, aktivitas tubuh dan kondisi fisiologis khusus untuk mencapai derajat kesehatan yang optimal. Angka Kecukupan Gizi (AKG) protein remaja putri untuk kelompok umur 16-18 tahun sebesar 65 gr, vitamin $\mathrm{C} 75 \mathrm{mg}$ dan zat besi $15 \mathrm{mg}$ (Kemenkes, 2019). Asupan gizi dikategorikan baik jika berada pada rentang 80-100\% AKG (Laksmi, 2009). Deskripsi asupan gizi remaja putri di wilayah perkotaan dan pedesaan dapat dilihat pada tabel 3.

Tabel 3. Deskripsi asupan gizi remaja putri di wilayah perkotaan dan pedesaan

\begin{tabular}{|c|c|c|c|c|}
\hline \multirow{2}{*}{ Variabel } & \multicolumn{2}{|c|}{ Perkotaan } & \multicolumn{2}{|c|}{ Pedesaan } \\
\hline & $\mathrm{n}$ & $\%$ & $\mathrm{~N}$ & $\%$ \\
\hline \multicolumn{5}{|l|}{ Asupan protein } \\
\hline - $\quad$ Lebih (> 59 gr) & 55 & 84,6 & 44 & 67,7 \\
\hline - $\quad$ Baik $(47,2-59 \mathrm{mg})$ & 7 & 10,8 & 10 & 15,4 \\
\hline - $\quad$ Kurang $(<47,2 \mathrm{mg})$ & 3 & 4,6 & 11 & 16,9 \\
\hline - $\quad$ Rerata \pm SD & \multicolumn{2}{|c|}{$80,81 \pm 2,26$} & \multicolumn{2}{|c|}{$65,42 \pm 1,69$} \\
\hline \multicolumn{5}{|l|}{ Asupan vitamin $\mathrm{C}$} \\
\hline - $\quad$ Lebih (> 75 gr) & 26 & 40,0 & 30 & 46,2 \\
\hline - $\quad$ Baik (60-75 mg) & 7 & 10,8 & 3 & 4,6 \\
\hline - $\quad$ Kurang $(<60 \mathrm{mg})$ & 32 & 49,2 & 32 & 49,2 \\
\hline - $\quad$ Rerata \pm SD & \multicolumn{2}{|c|}{$71,75 \pm 4,78$} & \multicolumn{2}{|c|}{$79,65 \pm 6,47$} \\
\hline \multicolumn{5}{|l|}{ Asupan zat besi } \\
\hline - $\quad$ Lebih (> 26 gr) & 1 & 3,1 & 0 & 0 \\
\hline - $\quad$ Baik $(20,8-26 \mathrm{mg})$ & 0 & 0 & 0 & 0 \\
\hline - $\quad$ Kurang $(<20,8 \mathrm{mg})$ & 63 & 96,9 & 65 & 100 \\
\hline - $\quad$ Rerata \pm SD & \multicolumn{2}{|c|}{$12,47 \pm 5,28$} & \multicolumn{2}{|c|}{$8,83 \pm 3,15$} \\
\hline
\end{tabular}

Tabel 3 menunjukkan rerata asupan protein remaja putri di wilayah perkotaan (80,81 gr) lebih banyak dibandingkan asupan protein remaja putri di wilayah 
pedesaan (65,42 gr). Proporsi remaja putri dengan tingkat asupan protein kurang terdapat pada $16,5 \%$ remaja putri di wilayah pedesaan yang lebih banyak dibandingkan remaja putri di wilayah perkotaan $(4,6 \%)$. Rerata asupan vitamin $\mathrm{C}$ remaja putri di wilayah perkotaan sebesar $71,75 \mathrm{mg}$ dan pada remaja putri di wilayah pedesaan 79,65 mg, proporsi asupan vitamin C kurang pada remaja putri di wilayah perkotaan dan pedesaan sebesar 49,2\%.

Defisit asupan zat besi terdapat pada kedua kelompok remaja putri yaitu rerata $12,47 \mathrm{mg}$ pada remaja putri di wilayah perkotaan dan $8,83 \mathrm{mg}$ pada remaja putri di wilayah pedesaan. Proporsi asupan zat besi kurang pada remaja putri di wilayah perkotaan sebesar 96,9\% dan pada remaja putri di wilayah pedesaan sebesar $100 \%$. Analisa statistik perbedaan status anemia, status gizi dan asupan gizi (protein, vitamin $\mathrm{C}$, zat besi) remaja putri di wilayah perkotaan dan pedesaan dapat dilihat pada tabel 4 .

Tabel 4. Perbedaan status anemia, status gizi dan asupan gizi (protein, vitamin c, zat besi) remaja putri di wilayah perkotaan dan pedesaan

\begin{tabular}{|c|c|c|c|c|c|c|c|}
\hline \multirow[t]{2}{*}{ Variabel } & \multicolumn{3}{|c|}{ Perkotaan } & \multicolumn{3}{|c|}{ Pedesaan } & \multirow{2}{*}{$p$} \\
\hline & Min & Max & Rerata \pm SD & Min & Max & Rerata \pm SD & \\
\hline $\begin{array}{l}\text { Status Anemia } \\
\text { (nilai kadar } \mathrm{Hb} \text { ) }\end{array}$ & 8,3 & 19 & $12,87 \pm 1,78$ & 8 & 18,2 & $12,43 \pm 2,06$ & $0,195^{\mathrm{a}}$ \\
\hline $\begin{array}{l}\text { Status Gizi (nilai z- } \\
\text { skor) }\end{array}$ & $-2,7$ & 2,95 & $0,38 \pm 1,18$ & $-2,64$ & 3,14 & $0,01 \pm 1,12$ & $0,068^{\mathrm{a}}$ \\
\hline Asupan Protein & 42 & 134,7 & $80,81 \pm 2,26$ & 32,8 & 103,8 & $65,42 \pm 1,69$ & $0,000^{\mathrm{b}}$ \\
\hline Asupan Vitamin C & 2,5 & 214,5 & $71,75 \pm 4,78$ & 5,1 & 289,717 & $79,65 \pm 6,47$ & $0,874^{b}$ \\
\hline Asupan Zat Besi & 2,9 & 30 & $12,47 \pm 5,28$ & 3,3 & & $8,83 \pm 3,15$ & $0,000^{\mathrm{b}}$ \\
\hline
\end{tabular}

Tabel 4 menunjukkan tidak ada perbedaan yang bermakna pada status anemia, status gizi dan asupan vitamin $\mathrm{C}$ remaja putri di wilayah perkotaan dengan remaja putri di wilayah pedesaan. Rerata nilai kadar $\mathrm{Hb}$ dan nilai z-skor di kedua kelompok berada pada kategori baik. Rerata asupan vitamin C baik pada remaja putri di wilayah perkotaan dan lebih di wilayah pedesaan.

Terdapat perbedaan asupan protein antara remaja putri di wilayah perkotaan dan remaja putri di wilayah pedesaan $(p=0,000)$ dengan rerata asupan protein remaja putri di wilayah perkotaan adalah baik $(80,81$ gr) dan rerata asupan protein remaja 
putri di wilayah pedesaan kurang $(65,42$ gr). Rerata asupan zat besi remaja putri di wilayah perkotaan $(12,47 \mathrm{mg})$ lebih besar dari asupan zat besi remaja putri di wilayah pedesaan $(8,83 \mathrm{mg})$. Terdapat perbedaan asupan zat besi antara remaja putri di wilayah perkotaan dan remaja putri di wilayah pedesaan $(p=0,000)$.

\section{Pembahasan}

Anemia adalah suatu keadaan dimana kadar hemoglobin dan eritrosit lebih rendah daripada nilai normal, yang berbeda untuk setiap kelompok umur dan jenis kelamin sehingga berkurangnya fungsi pertukaran $\mathrm{O} 2$ dan $\mathrm{CO} 2$ diantara jaringan dan pembentukan sel darah merah dalam produksinya guna mempertahankan kadar hemoglobin pada tingkat normal (WHO, 2015). Prevalensi anemia sebagai masalah kesehatan masyarakat dikategorikan sebagai berikut: bukan masalah kesehatan masyarakat jika $<5 \%$, masalah kesehatan masyarakat tingkat ringan jika 5-19\%, masalah kesehatan tingkat sedang jika 20-39,9\%, dan merupakan masalah kesehatan tingkat berat jika $\geq 40 \%$ (Kemenkes RI, 2014).

Rerata kadar $\mathrm{Hb}$ remaja putri di wilayah perkotaan maupun pedesaan pada kategori normal sedangkan prevalensi status anemia remaja putri di wilayah perkotaan sebesar $26,2 \%$ dan $32,3 \%$ remaja putri di wilayah pedesaan yang menunjukkan adanya masalah kesehatan masyarakat tingkat sedang (20-39,9\%). Beberapa penelitian terdahulu sebagian besar menunjukkan prevalensi anemia pada tingkat masalah kesehatan ringan hingga berat yaitu 45,7\%, 39\%, 42,5\%, 90\%, 51,3\% dan 41\% (Agrawal A et al 2018, Khumar A et al 2018, Hamal S et al 2018, Upadhye JV et al, 2017, Kanodia P et al 2016, Biradar SS et al 2012). Faktor yang dapat mempengaruhi kadar $\mathrm{Hb}$ pada remaja putri diantaranya adalah kehilangan darah akibat menstruasi, kurangnya zat besi dalam makanan yang dikonsumsi, ketidakseimbangan antara asupan gizi dan aktivitas yang dilakukan.

Konsumsi makanan yang tidak seimbang dengan kebutuhan zat gizi dapat menyebabkan tubuh tidak berada dalam status gizi yang baik. Remaja putri dengan status gizi kurus lebih banyak ditemukan pada wilayah pedesaan tetapi status gizi gemuk dan obesitas lebih banyak pada remaja putri di wilayah perkotaan. Penelitian Sinha S et al (2016) dengan desain cross sectional membandingkan status gizi remaja putri di wilayah perkotaan dan pedesaan Lucknow India. Prevalensi kelebihan berat badan remaja putri di wilayah perkotaan lebih besar $(6,25 \%)$ dibandingkan remaja putri di wilayah pedesaan (5,72\%). Penelitian yang dilakukan Pavithran S et al (2018) 
mengenai status gizi remaja putri di wilayah pedesaan Dharwad menunjukkan hasil $25,2 \%$ remaja putri dengan status gizi kurus dan 3,7\% status gizi lebih, terdapat prevalensi kurang gizi yang tinggi di kalangan remaja putri dan kurang gizi dikaitkan dengan defisiensi mikro-nutrien seperti anemia.

Asupan zat gizi merupakan jumlah zat gizi yang masuk melalui konsumsi makanan sehari-hari untuk memperoleh energi guna melakukan kegiatan fisik seharihari. Pada sepertiga negara di dunia, lebih dari seperempat remaja putri telah memiliki anak. Mengatasi kehamilan remaja serta asupan gizi pada remaja sangat penting dilakukan mengingat bahwa komplikasi selama kehamilan dan persalinan adalah penyebab utama kematian remaja putri umur 15-19 secara global (WHO, 2017).

Asupan protein kategori kurang lebih banyak terdapat pada remaja putri di wilayah pedesaan dibandingkan remaja putri di wilayah perkotaan, hampir separuh asupan vitamin $\mathrm{C}$ kurang pada remaja putri di kedua wilayah dan defisit asupan zat besi terdapat pada kedua kelompok remaja putri, Asupan zat gizi sehari-hari sangat dipengaruhi oleh kebiasaan makan. Konsumsi sumber makanan yang mengandung zat besi yang kurang maupun konsumsi makan cukup tetapi makanan yang dikonsumsi memiliki bioavaibilitas zat besi yang rendah dapat menyebabkan jumlah zat besi yang diserap oleh tubuh kurang.

Terdapat perbedaan asupan protein dan zat besi antara remaja putri di wilayah perkotaan dan pedesaan. Gasong et al (2019) melakukan penelitian dengan desain cross sectional pada remaja putri di Nusa Tenggara Timur, terdapat nilai korelasi asupan zat besi dan kadar $\mathrm{Hb}$ sebesar 0,360 yang artinya semakin tinggi asupan zat besi maka semakin tinggi pula kadar Hb. Penelitian Sumarmi (2017) menyimpulkan ada hubungan antara asupan protein $(\mathrm{p}=0,027)$ dengan status anemia. Protein berperan penting dalam transportasi zat besi di dalam tubuh oleh karena itu, kurangnya asupan protein akan mengakibatkan transportasi zat besi terhambat sehingga akan terjadi defisiensi besi. Kebiasaan makan positif pada remaja putri yang tidak anemia adalah sering mengkonsumsi protein hewani, memilih buah sumber vitamin $\mathrm{C}$ dan memilih snack bergizi. 


\section{SIMPULAN}

Prevalensi status anemia remaja putri di wilayah pedesaan lebih tinggi daripada remaja putri di wilayah perkotaan. Ada perbedaan asupan protein dan zat besi remaja putri di wilayah perkotaan dibandingkan pedesaan dengan rerata asupan protein dan zat besi remaja putri di wilayah pedesaan lebih rendah daripada remaja putri di wilayah perkotaan

Perlu perhatian lebih lanjut untuk meningkatkan kebutuhan gizi terutama asupan makanan sumber protein dan zat besi bagi remaja putri di wilayah pedesaan. Advokasi berkelanjutan untuk masalah gizi remaja harus dilakukan untuk memastikan bahwa remaja menerima zat gizi optimal untuk mendukung pertumbuhan dan perkembangan mereka. Masa remaja merupakan saat yang tepat untuk mengatasi masalah gizi yang terjadi di masa kanak-kanak dan sebagai dasar bagi status gizi yang baik di masa dewasa.

\section{DAFTAR PUSTAKA}

Agrawal A, Shetty A, Jacob GP, Kamath A. Anaemia among Adolescents in a Coastal District of India.Natl J Community Med 2018;9(6):396-401

Arisman, 2010. Buku Ajar Ilmu Gizi.Gizi Dalam Daur Kehidupan. Jakarta: EGC.

Badan Penelitian dan Pengembangan Kesehatan Kementerian Kesehatan (Balitbangkes) RI. Riset Kesehatan Dasar RISKESDAS 2013. Balitbangkes Kemenkes RI; 2013.

Badan Penelitian dan Pengembangan Kesehatan Kementerian Kesehatan (Balitbangkes) RI. Riset Kesehatan Dasar RISKESDAS 2018. Balitbangkes Kemenkes RI; 2018.

Badan Penelitian dan Pengembangan Kesehatan Kementerian Kesehatan (Balitbangkes) RI. Studi Diet Total : Survei Konsumsi Makanan Individu Indonesia 2014. Balitbangkes Kemenkes RI; 2014.

Biradar, SS, SomaSheKar p. Biradar SP, Alatagi AC et al, Prevalence of Anaemia among Adolescent Girls: A One Year Cross-Sectional Study.Journal of Clinical and Diagnostic Research. 2012 May (Suppl-1), Vol-6(3):372-377.

Brown, J. 2005. Nutrition Through the Life Cycle. USA: Wadsworth. 
Hamal S, Dhungana GP, Shrestha P, Niraj KC. Prevalence of anaemia and its associated factors amongschool adolescent girls in Baglung municipality, Nepal. www.gjmedph.com Vol. 7, No. 52018.

Gasong LS, Damayanthi E, Marliyati SA, Martianto D. The Relationship Between Nutritional Status And Nutrient Intake With Anemia Incidence In Adolescent Girls In Kupang Indonesia. IJPSR, 2019; Vol. 10(9): 4251-4256.

Kanodia P, Bhatta M, Singh RR, Bhatta NK, Shah GS. A study of anemia among adolescent girls in eastern part of Nepal. JCMS Nepal. 2016;12(1):19-22

Kemenkes. 2011. Keputusan Menteri Kesehatan Republik Indonesia No. 1995/Menkes/SK/XII/2010 tentang Standar Antropometri Penilaian Status Gizi Anak. Kementerian Kesehatan RI.

Kemenkes. 2019. Peraturan Menteri Kesehatan Republik Indonesia No. 28 Tahun 2019 tentang Angka Kecukupan Gizi yang Dianjurkan untuk Masyarakat Indonesia. Kementerian Kesehatan RI.

Kemenkes, 2014. Pedoman Gizi Seimbang. Kementerian Kesehatan RI.

Kumar A, Goyal A, Verma N, et al. Study of anemia among adolescent school girls and young adults. Int J Adv Med. 2018 Aug;5(4):877-881

Laksmi. Survei Konsumsi Gizi. Semarang : Universitas Diponegoro : 2009

Pavithran S, Bant DD. Nutritional status of adolescent school girls residing in rural areas of Dharwad district, India: a cross sectional study. Int J Community Med Public Health. 2018 Jul;5(7):2761-2765.

Sumarmi S, Akib A. Kebiasaan Makan Remaja Putri yang Berhubungan dengan Anemia : Kajian Positive Deviance. Amerta Nutr (2017) 105-116.

Soetjiningsih. 2010.Tumbuh Kembang Remaja dan Permasalahannya. Jakarta : Sagung Seto.

Sediaoetama AD. 2010. Ilmu Gizi. Jakarta, Dian Rakyat

Sinha S, Singh RB. A study on diet and nutritional status among adolescent girls in Lucknow district, India. Int J Community Med Public Health. 2016 Aug;3(8):2019-2025

Teji K, Dessie Y, Assebe T, Abdo M. Anaemia and nutritional status of adolescent girls in Babile District, Eastern Ethiopia. Pan African Medical Journal. 2016; 24:62. 
Upadhye JV, Upadhye JJ. Assessment of anaemia in adolescent girls. Int J Reprod Contracept Obstet Gynecol. 2017 Jul;6(7):3113-3117

WHO. 2008. Worldwide prevalence of anaemia 1993-2005, WHO Global Database on Anaemia. Geneva, World Health Organization.

WHO, 2015. The Global Prevalence of Anaemia in 2011. Geneva : World Health Organization.

WHO, 2014. Health for the World's Adolescents, a second chance in the second decade. Geneva : World Health Organization.

WHO. 2017. Global Accelerated Action for the Health of Adolescents (Aa-Ha!): Guidance to Support Country Implementation. Summary. Geneva: World Health Organization.

Widyastuti P., Hardiyanti E A., 2010. Gizi Kesehatan Masyarakat. Jakarta: EGC.

Sulistyoningsih H. Gizi untuk Kesehatan Ibu dan Anak. Yogyakarta: Graha Ilmu: 2011.

Sumarmi S, Akib A. Kebiasaan Makan Remaja Putri yang Berhubungan dengan Anemia: Kajian Positive Deviance. Amerta Nutr (2017) 105-116.

Supariasa DN, Bakri B, Fajar I. 2011. Penilaian Status Gizi. Jakarta : Buku Kedokteran EGC.

Santrock JW. 2002 Adolescence Perkembangan Remaja. Jakarta: Erlangga.

Soetjiningsih. 2010.Tumbuh Kembang Remaja dan Permasalahannya. Jakarta : Sagung Seto.

Sediaoetama AD. 2010. Ilmu Gizi. Jakarta, Dian Rakyat

Teji K, Dessie Y, Assebe T, Abdo M. Anaemia and nutritional status of adolescent girls in Babile District, Eastern Ethiopia. Pan African Medical Journal. 2016; 24:62.

Wirjatmadi B, Adriani M. Peran Gizi dalam Siklus Kehidupan. Jakarta: Kencana: 2016.

World Health Organization. 2008. Worldwide prevalence of anaemia 1993-2005, WHO Global Database on Anaemia. Geneva, WHO.

World Health Organization, 2015. The Global Prevalence of Anaemia in 2011. Geneva : WHO.

World Health Organization, 2014. Health for the World's Adolescents, a second chance in the second decade. Geneva: WHO. 